\title{
Carbon dioxide assimilation and photosynthetic electron transport of tea leaves under nitrogen deficiency
}

\author{
Zheng-he Lin ${ }^{*}$, Qiu-sheng Zhong, Chang-song Chen ${ }^{\dagger}$, Qi-chun Ruan, Zhi-hui Chen and Xiao-mei You
}

\begin{abstract}
Background: Tea plant is famed in humid and sub-humid of tropical regions, sub-tropical regions, and is a leafharvested crop. Nitrogen is the most important nutrient for increasing quality of tea leaves. Therefore, large amounts of nitrogen fertilizer are increasingly applied by tea farmers. Appropriate application of nitrogen fertilizer aroused people's concern. This research of physiological response to $\mathrm{N}$ deficiency stress will be helpful for appropriate application of nitrogen fertilizer for tea farmers and elucidate a mechanistic basis for the reductions in carbon dioxide $\left(\mathrm{CO}_{2}\right)$ assimilation.

Results: To elucidate a mechanistic basis for the reductions in carbon dioxide $\left(\mathrm{CO}_{2}\right)$ assimilation under nitrogen (N) deficiency tea leaves, changes in chlorophyll (Chl), carbohydrates, ribulose-1,5-bisphosphate carboxylase/oxygenase (Rubisco) and chlorophyll fluorescence transient were examined together with six $\mathrm{N}$ treatment $(0,50,100$, 300,1200 or $6000 \mu \mathrm{M} N$ ). Root, stem and leaves dry weight (DW) increased as N supply increased from 0 to $300 \mu \mathrm{M}$, then remained unchanged. The reductions in $\mathrm{CO}_{2}$ assimilation of $\mathrm{N}$-deficient leaves paralleled with high intercellular $\mathrm{CO}_{2}$ concentration. Rubisco activity, protein and $\mathrm{Chl}$ content increased linearly or curvilinearly over the range of leaf $\mathrm{N}$ content examined except unchanged as leaf $\mathrm{N}$ from 2.15 to $2.79 \mathrm{~g} \mathrm{~m}^{-2}$. Chlorophyll fluorescence transient from $\mathrm{N}$-deficient leaves displayed a depression at the P-step, accompanied by a new step at about $150 \mu \mathrm{s}\left(\mathrm{L}\right.$-step). $\mathrm{F}_{\mathrm{v}} / \mathrm{F}_{\mathrm{m}^{\prime}}$ $\mathrm{RE}_{0} / \mathrm{ET}_{\mathrm{o}}, \mathrm{ET}_{0} / \mathrm{ABS}, \mathrm{S}_{\mathrm{m}}, \mathrm{ET}_{\mathrm{o}} / \mathrm{CS}_{0}, \mathrm{Pl}_{\text {abs }}, \mathrm{PI}_{\text {tot, abs }}$, were decreased in $\mathrm{N}$-deficient leaves but increased $\mathrm{DI}_{0} / \mathrm{CS}_{0}, \mathrm{DI}_{0} / \mathrm{RC}$ and $\mathrm{DI}_{\mathrm{o}} / \mathrm{ABS}$. Regressive analysis showed that $\mathrm{CO}_{2}$ assimilation decreased linearly or curvilinearly with decreasing initial rubisco, $\mathrm{Pl}_{\text {abs }}$ and Leaf Chl, respectively. Therefore, we concluded the decreased photosynthetic electron transport capacity, leaf chl content and initial rubisco activity are probably the main factors contributing to decreased $\mathrm{CO}_{2}$ assimilation under $\mathrm{N}$ deficiency.
\end{abstract}

Conclusions: The decreased photosynthetic electron transport capacity, leaf Chl content and initial rubisco activity are probably the main factors contributing to decreased $\mathrm{CO}_{2}$ assimilation under $\mathrm{N}$ deficiency.

Keywords: Tea plant, Nitrogen deficiency, $\mathrm{CO}_{2}$ assimilation, Chlorophyll fluorescence

\section{Background}

Tea [Camellia sinensis (L.) O.Kuntze] is an evergreen shrub native to China and cultivated in humid and subhumid of tropical, sub-tropical, and temperate regions of the world mainly on acid soils (Lin et al. 2009). China is the world's largest tea-producing country, and its tea

\footnotetext{
*Correspondence: linzhenghe@126.com

${ }^{\dagger}$ Zheng-he Lin and Chang-song Chen contributed equally to this work

Tea Research Institute, Fujian Academy of Agricultural Sciences,

Fuan 355000, China
}

plantation area had reached 2.87 million hectare (ha) up to 2015 , contributing approximately $50 \%$ to the world total (Liang and Shi 2015). In addition, tea is a leaf-harvested crop, and nitrogen is the most important nutrient (Silva et al. 2015) for increasing the content of free amino acids, an index of the quality of tea leaves (Tokuda and Hayatsu 2004; Yao et al. 2015). For improving the yield and quality of tea leaves, therefore, large amounts of nitrogen fertilizer are increasingly applied by tea farmers. For instance, the application rates of nitrogen 
fertilizer to tea plantations have been as high as 450$1200 \mathrm{~kg} \mathrm{~N} \mathrm{ha}^{-1}$ year $^{-1}$, which significantly surpasses the recommended rate of $250-375 \mathrm{~kg} \mathrm{~N} \mathrm{ha}^{-1}$ year $^{-1}$ for high tea yields (Tokuda and Hayatsu 2004; Hirono and Nonaka 2012; Fu et al. 2012; Zhu et al. 2014). Not surprisingly, such high nitrogen inputs can easily induce excess residual nitrogen and acidification of soil; both influence the nitrogen cycle of tea fields in which a great deal of nitrogenous gases are produced (Jumadi et al. 2008; Zhu et al. 2014). Despite such use, soil $N$ deficiency remains a major constraint on crop productivity in many developing countries. Therefore, increasing tea plant tolerance to low-N conditions would improve tea production, especially in regions with low soil N levels (Wei et al. 2016).

The yield of leaves and leaf photosynthetic rate are directly linked to plant dry matter production. The extent of photosynthesis during tea plant growing can be affected by many factors, including tea cultivars, altitude, climatic condition, $\mathrm{CO}_{2}$ level, soil condition and temperature. Another major factor affecting photosynthesis is the available $\mathrm{N}$ level of the soil (Wei et al. 2016; Jaaffar and Gardner 1988). Given the diverse roles that nitrogen plays in plant physiology and development, $\mathrm{N}$ deficiency has a crippling effect on plants. $\mathrm{N}$ deficiency significantly reduces a plant's capacity for photosynthesis (Boussadia et al. 2010) by reducing the rates of leaf photosynthesis and new leaf area expansion. Furthermore, $\mathrm{N}$ deficiency leads to the degradation of photosynthetic pigments and proteins, and reduced enzyme synthesis in plants (Polesskaya et al. 2004). Therefore, $\mathrm{N}$ deficiency leads to changes in the expression levels of proteins, as well as the activity levels of enzymes, which invariably leads to changes in plant metabolism (Wei et al. 2016). For example, N levels affect the post-translational modification of phosphoenolpyruvate carboxylase (PEPCase) (Prinsi et al. 2009). Earlier studies in several other crops have also indicated that $\mathrm{N}$ deficiency reduces ribulose bisphosphate carboxylase/oxygenase (Rubisco) activity (Chen and cheng 2003, 2004), as well as reducing the actual amount of Rubisco produced by the plant. In addition, $\mathrm{N}$ deficiency impacts overall plant metabolism through wide reprogramming of primary and secondary metabolic pathways (Scheible et al. 2004).

The chlorophyll fluorescence transient has been found to be a sensitive indicator of photosynthetic electron transport processes (Tóth et al. 2007). The transient is considered to be determined by changes in the redox state of primary quinine acceptor $\left(\mathrm{Q}_{\mathrm{A}}\right)$ (Lazár 2006; Lin et al. 2009), but at the same time, the transient reflects the reduction of the photosynthetic electron transport chain (Schansker et al. 2005; Lin et al. 2009). The chlorophyll fluorescence transient was applied in numerous studies in crop plants, e.g. to assess the environmental effects in wheat, such as drought (Živčák et al. 2008), high temperature (Brestič et al. 2012), light stress (Kalaji et al. 2012; Živčák et al. 2014). The chlorophyll fluorescence transient were applied several times also in studies dealing with nitrogen deficiency in plants and the effect of poor nitrogen supply on photosystem II (PSII) is recently well described (Lu et al. 2001; Redillas et al. 2011; Li et al. 2012). Although in many of published works the rapid chlorophyll fluorescence is denoted as a useful tool for assessing the physiological effects of nitrogen deficiency on plants, there is still a lack of data on the usefulness of the method in assessment of plant photosynthetic performance in crop trials with different nitrogen supply. Thus, it is not well known how $\mathrm{N}$ deficiency affects photosynthetic electron transport in tea plant.

Gaining a more complete mechanistic picture of how plants adapt and respond to low $\mathrm{N}$ conditions is important since $\mathrm{N}$ plays important roles in growth and physiology. This is especially critical for crops like tea, which serves as one of the most popular beverages worldwide (Khokhar and Magnusdottir 2002; Topuz et al. 2014). In addition, a better understanding of the proteins, $\mathrm{CO}_{2}$ assimilation and photosynthetic electron transport that influence responses to low $\mathrm{N}$ can improve the utilisation efficiency of $\mathrm{N}$ fertilisers and assist in developing better methods to evaluate plant responses to possible deficiencies. In this study, we aimed to determine how $\mathrm{N}$ deficiency affects $\mathrm{CO}_{2}$ assimilation, Rubisco, non-structural carbohydrates and photosynthetic electron transport in tea leaves to understand the mechanism by which $\mathrm{N}$ deficiency leads to a decrease in $\mathrm{CO}_{2}$ assimilation.

\section{Methods}

\section{Plant materials and $\mathrm{N}$ treatments}

The experiment was completed in 2015 in study plot of Tea Research Institute, Fujian Academy of Agricultural Sciences, by using 9-mouth-old uniform tea (Camellia sinensis (L.) O. Kuntze $c v$. Benshan) trees potted in $6 \mathrm{~L}$ argil pots that were filled with river sand, 2 seedlings per pot, and cultivated in the natural temperature and light conditions. Nutrient solution was prepared by referring to (Lin et al. 2009), and full-strength nutrient solution contained $3 \mathrm{mmol} \mathrm{L}-1 \mathrm{NH}_{4} \mathrm{NO}_{3}, 0.5 \mathrm{mmol} \mathrm{L}^{-1}$ $\mathrm{Ca}\left(\mathrm{H}_{2} \mathrm{PO}_{4}\right)_{2}, 1.0 \mathrm{mmol} \mathrm{L}^{-1} \mathrm{~K}_{2} \mathrm{SO}_{4}, 0.5 \mathrm{mmol} \mathrm{L}^{-1} \mathrm{CaCl}_{2}$, $0.6 \mathrm{mmol} \mathrm{L}^{-1} \mathrm{MgSO}_{4}, 46 \mu \mathrm{mol} \mathrm{L}{ }^{-1} \mathrm{H}_{3} \mathrm{BO}_{3}, 9 \mu \mathrm{mol} \mathrm{L}^{-1}$ $\mathrm{MnSO}_{4}, 9 \mu \mathrm{mol} \mathrm{L}{ }^{-1} \mathrm{ZnSO}_{4}, 2 \mu \mathrm{mol} \mathrm{L} \mathrm{L}^{-1} \mathrm{CuSO}_{4}$, $2.6 \mu \mathrm{mol} \mathrm{L}{ }^{-1} \mathrm{Na}_{2} \mathrm{MoO}_{4}$ and $30 \mu \mathrm{mol} \mathrm{L}^{-1} \mathrm{Fe}$-EDTA. Seven weeks after transplanting, the treatment was applied for 18 weeks: until the end of the experiment, each pot was supplied three times weekly with $500 \mathrm{~mL}$ of nutrient solution at a $\mathrm{N}$ concentration of $0,50,100,300,1200$ or $6000 \mu \mathrm{M}$ from $\mathrm{NH}_{4} \mathrm{NO}_{3}$ at $\mathrm{pH}$ of 5.0. At the end of the experiment, the fully-expanded (about 7 weeks old) 
leaves from different replicates and treatments were used for all the measurements. Leaf discs $\left(0.63 \mathrm{~cm}^{2}\right.$ in size $)$ were collected at noon under full sun and immediately frozen in liquid $\mathrm{N}_{2}$. Samples were stored at $-80{ }^{\circ} \mathrm{C}$ until they were used for the determination of Chl, Rubisco, carbohydrates, and protein. Special care was taken to ensure that all samples were transferred directly from liquid $\mathrm{N}_{2}$ to freezer of $-80{ }^{\circ} \mathrm{C}$, at no time were any samples exposed to room temperature.

\section{Measurements of root, stem and leaf DW}

At the end of the experiment, 10 plants per treatment from different pots were harvested. The plants were divided into their separate parts (roots, stems and leaves). The plant material was then dried at $80{ }^{\circ} \mathrm{C}$ for $48 \mathrm{~h}$ and the DW measured. Specific leaf weight was measured according to Syvertsen et al. (1980).

Determination of leaf total soluble protein, $\mathrm{Chl}$, and total N $\mathrm{Chl}, \mathrm{Chl} \mathrm{a}$ and $\mathrm{Chl} \mathrm{b}$ were assayed according to Lichtenthaler (1987). Briefly, 2 frozen leaf discs were extracted with $8 \mathrm{~mL}$ of $80 \%(\mathrm{v} / \mathrm{v})$ acetone for $24 \mathrm{~h}$ in the dark. The extracts were determined using Libra S22 ultraviolet-visible spectrophotometer (Biochrom Ltd., Cambridge, UK). Leaf total soluble protein was extracted with $50 \mathrm{mM} \mathrm{Na} \mathrm{HPO}_{4}-\mathrm{KH}_{2} \mathrm{PO}_{4}(\mathrm{pH} 7.0)$ and $5 \%(\mathrm{w} / \mathrm{v})$ insoluble polyvinyl-polypyrrolidone (PVPP), and determined according to Bradford (1976) using bovine serum albumin (BSA) as standard. Total $\mathrm{N}$ was measured using a continuous flow auto-analyser (AAIII; SEAL Analytical, Germany).

\section{Leaf gas exchange measurements}

Measurements were made with a Li-6400 portable photosynthesis system (PP systems, Herts, UK) at ambient $\mathrm{CO}_{2}$ concentration under a controlled light intensity of $1000 \mu \mathrm{mol} \mathrm{m}^{-2} \mathrm{~s}^{-1}$ between 9:30 and 11:30 on a clear day. During measurements, leaf temperature and vapor pressure deficit (VPD) were $25.9 \pm 1.0^{\circ} \mathrm{C}$ and $1.9 \pm 0.1 \mathrm{kPa}$, respectively.

\section{Leaf Rubisco activity measurements}

Two frozen leaf discs from the same leaf were ground with a pre-cooled mortar and pestle in $1 \mathrm{~mL}$ of extraction buffer containing $50 \mathrm{mM}$ Hepes-KOH (pH 7.5), $10 \mathrm{mM}$ $\mathrm{MgCl}_{2}, 2 \mathrm{mM}$ ethylenediaminetetraacetic acid (EDTA), $10 \mathrm{mM}$ dithiothreitol (DDT), 1\% (v/v) Triton X-100, 5\% $(\mathrm{w} / \mathrm{v})$ insoluble PVPP, $1 \%(\mathrm{w} / \mathrm{v})$ BSA, 10\% (v/v) glycerol. The extract was centrifuged at $13,000 \mathrm{~g}$ for $60 \mathrm{~s}$ in $2{ }^{\circ} \mathrm{C}$, and the supernatant was used immediately for the assay of Rubisco activity. Rubisco activity was determined according to Lin et al. (2009). For initial activity, $50 \mu \mathrm{L}$ of sample extract was added to a cuvette containing $900 \mu \mathrm{L}$ of an assay solution, immediately followed by adding $50 \mu \mathrm{L}$ of $10 \mathrm{mM}$ ribulose-1,5-bisphosphate (RuBP), then mixing well. The change of absorbance at $340 \mathrm{~nm}$ was monitored for $40 \mathrm{~s}$. For total activity, $50 \mu \mathrm{L}$ of $10 \mathrm{mM}$ $\mathrm{RuBP}$ was added $15 \mathrm{~min}$ later, after $50 \mu \mathrm{L}$ of sample extract was combined with $900 \mu \mathrm{L}$ of an assay solution to fully activate all the Rubisco. The assay solution for both initial and total activity measurements, whose final volume was $1 \mathrm{~mL}$, contained $100 \mathrm{mM}$ Hepes- $\mathrm{KOH}(\mathrm{pH}$ 8.0), $25 \mathrm{mM} \mathrm{KHCO}_{3}, 20 \mathrm{mM} \mathrm{MgCl}, 3.5 \mathrm{mM}$ ATP, $5 \mathrm{mM}$ phosphocretaine, 5 units NAD-glyceraldehyde-3-phosphate dehydrogenase (NAD-GAPDH), 5 units 3-phosphoglyceric phospokinase (PCK), 17.5 units creatine phosphokinase (CPK), $0.25 \mathrm{mM} \mathrm{NADH}, 0.5 \mathrm{mM}$ RuBP, and $50 \mu \mathrm{L}$ sample extract. Rubisco activation state was calculated as the ratio of initial activity to total activity.

\section{Assay of leaf nonstructural carbohydrates}

Sucrose, fructose, glucose and starch were extracted 3 times with $80 \%(\mathrm{v} / \mathrm{v})$ ethanol at $80{ }^{\circ} \mathrm{C}$ and determined according to Chen and Cheng (2003).

\section{Measurements of leaf chlorophyll fluorescence transients} Chlorophyll fluorescence transient was measured by a Handy Plant Efficiency Analyzer (Handy PEA, Hansatech Instruments Limited, Norfolk, UK) according to Strasser et al. (1995). All the measurements were done with $3 \mathrm{~h}$ dark-adapted plants at room temperature. Chlorophyll fluorescence transient was induced by $3400 \mu \mathrm{mol} \mathrm{m}^{-2} \mathrm{~s}^{-1}$ red light, which was provided by three luminous diodes (peak value of $650 \mathrm{~nm}$ ), and the light was focused on the leaves, evenly illuminated on the exposed/(diameter of $4 \mathrm{~mm}$ ) surface. At the beginning $300 \mu \mathrm{s}$, data were read per $10 \mu \mathrm{s}$. With the slowing fluorescence dynamic signals, the time interval of data reading is prolonged. All determination work was conducted at room temperature $3 \mathrm{~h}$ after the plants were adapted to the dark condition, and repeat for every 5-7 (each leaf of the seeding repeats once).

For the following derivative parameters: $(1) \mathrm{V}_{\mathrm{J}}=\left(\mathrm{F}_{2 \mathrm{~ms}}-\mathrm{F}_{\mathrm{o}}\right)$ $/\left(F_{m}-F_{o}\right)$ denotes the relative variable fluorescence at point $\mathrm{J}(2 \mathrm{~ms}) ; \mathrm{V}_{\mathrm{I}}=\left(\mathrm{F}_{30 \mathrm{~ms}}-\mathrm{F}_{\mathrm{o}}\right) /\left(\mathrm{F}_{\mathrm{m}}-\mathrm{F}_{\mathrm{o}}\right)$ the relative variable fluorescence at point $\mathrm{I}(30 \mathrm{~ms})$; $\mathrm{S}_{\mathrm{m}}=\mathrm{EC}_{\mathrm{o}} / \mathrm{RC}=$ Area $/\left(\mathrm{F}_{\mathrm{m}}-\mathrm{F}_{\mathrm{o}}\right)$ the general electronic carrier of the reaction center; and $\mathrm{M}_{\mathrm{o}}=4\left(\mathrm{~F}_{300 \mu \mathrm{s}}-\mathrm{F}_{\mathrm{o}}\right) /$ $\left(\mathrm{F}_{\mathrm{m}}-\mathrm{F}_{\mathrm{o}}\right)$ the initial slope of chlorophyll fluorescence induction curve; (2) The energy used to capture the electron transfer of the unit reaction center (RC): dissipated energy in the $\mathrm{RC}: \mathrm{DI}_{\mathrm{o}} / \mathrm{RC}=\mathrm{ABS} / \mathrm{RC}-\mathrm{TR}_{\mathrm{o}} / \mathrm{RC}$; (3) the quantum yield and energy distribution ratio parameters: the maximum photochemical efficiency $\varphi_{\text {Po }}=T_{\mathrm{o}} / \mathrm{ABS}=1-\mathrm{F}_{\mathrm{o}} / \mathrm{F}_{\mathrm{m}}=\mathrm{F}_{\mathrm{v}} / \mathrm{F}_{\mathrm{m}}$; quantum yield for electron transfer $\varphi_{\mathrm{Eo}_{\mathrm{o}}}=\mathrm{ET}_{\mathrm{o}} / \mathrm{ABS}=\mathrm{F}_{\mathrm{v}} / \mathrm{F}_{\mathrm{m}} \times\left(1-\mathrm{V}_{\mathrm{J}}\right)$; 
Fig. 1 Leaf $\mathrm{N}$ content $(\mathbf{A})$, root dry weight $(\mathbf{B})$, stem dry weight $(\mathbf{C})$, leaf dry weight $(\mathbf{D})$ and root/shoot dry weight ratio $(\mathbf{E})$ of tea trees in relation to nitrogen (N) supply $\left(0,50,100,300,1200\right.$ and $\left.6000 \mu \mathrm{mol} \mathrm{L}^{-1}\right)$. The data were examined using the least significant difference (LSD) test. Each point is mean \pm standard error $(n=5)$. Different letters above or below standard error bars indicate significant difference at $\mathrm{P}<0.05$

probability of electron transfer by the captured exciton to the electron transfer chain in exceeding other $\mathrm{Q}_{\mathrm{A}}$ electron acceptors $\psi_{\mathrm{Eo}}=\mathrm{ET}_{\mathrm{o}} / \mathrm{TR}_{\mathrm{o}}=\left(1-\mathrm{V}_{\mathrm{J}}\right)$; quantum yield ratio used for heat dissipation $\varphi_{\mathrm{Do}}=\mathrm{DI}_{\mathrm{o}} / \mathrm{ABS}=$ $1-\varphi_{\mathrm{Po}}=\mathrm{F}_{\mathrm{o}} / \mathrm{F}_{\mathrm{m}}$; (4) quantum yield of electron transfer in unit area $(\mathrm{t}=0) \mathrm{ET}_{\mathrm{o}} / \mathrm{CS}_{\mathrm{o}}=\varphi_{\mathrm{Eo}} \times\left(\mathrm{ABS} / \mathrm{CS}_{\mathrm{o}}\right)$; heat dissipation in unit area $(\mathrm{t}=0) \mathrm{DI}_{\mathrm{o}} / \mathrm{CS}_{\mathrm{o}}=\mathrm{ABS} /$ $\mathrm{CS}_{\mathrm{O}}-\mathrm{TR}_{\mathrm{o}} / \mathrm{CS}_{\mathrm{O}}$; (5) Performance index (PI): that is based on light absorption $\mathrm{PI}_{\mathrm{abs}}=\mathrm{RC} / \mathrm{ABS} \times\left[\varphi_{\mathrm{Po}} /\left(1-\varphi_{\mathrm{Po}}\right)\right] \times$ $\left[\psi_{\text {Eo }} /\left(1-\psi_{\text {Eo }}\right)\right]$; (6) Total PI, measuring the performance up to the PSI end electron acceptors $\mathrm{PI}_{\text {tot, abs }}=(\mathrm{RC} / \mathrm{ABS})$ $\times\left(\varphi_{\mathrm{Po}} /\left(1-\varphi_{\mathrm{Po}}\right)\right) \times\left(\psi_{\text {Eo }} /\left(1-\psi_{\text {Eo }}\right)\right) \times\left(\delta_{\mathrm{Ro}} /\left(1-\delta_{\mathrm{Ro}}\right)\right)$.

\section{Experimental design and statistical analysis}

There were 20 pots trees per treatment in a completely randomized design. Experiments were performed with 5-10 replicates (one tree from different pots per replicate). Differences among treatments were separated by the least significant difference (LSD) test at $\mathrm{P}<0.05$ level.

\section{Results}

\section{Leaf $\mathrm{N}$ content and plant growth characteristics}

As $\mathrm{N}$ supply decreased, leaf $\mathrm{N}$ content decreased curvilinearly (Fig. 1A). Root, stem and leaf dry weight increased as $\mathrm{N}$ supply increased from 0 to $300 \mu \mathrm{M}$, then remained unchanged (Fig. 1B-D), and resulted in a greater root $\mathrm{DW} /$ shoot $\mathrm{DW}$ ratio under $\mathrm{N}$ supply with 0 and $50 \mu \mathrm{M}$ (Fig. 1E).

\section{Leaf $\mathrm{Chl}$, soluble protein, gas exchange and Rubisco}

The total soluble protein contents (Fig. 2A) did not change significantly as leaf $\mathrm{N}$ decreased from 2.79 to $2.15 \mathrm{~g} \mathrm{~m}^{-2}$ then decreased significantly with further decreasing leaf $\mathrm{N}$ contents. Leaf Chl a (Fig. 2B), Chl b (Fig. 2C) and Chl (Fig. 2D) contents did not change significantly as leaf $\mathrm{N}$ decreased from 2.79 to $2.15 \mathrm{~g} \mathrm{~m}^{-2}$ then decreased with further decreasing leaf $\mathrm{N}$ content. The ratio of $\mathrm{Chl} \mathrm{a/b}$ (Fig. 2E) remained unchanged over the range of leaf $\mathrm{N}$ content examined.

Leaf $\mathrm{CO}_{2}$ assimilation (Fig. 3A) and stomatal conductance (Fig. $3 \mathrm{~B}$ ) increased as leaf $\mathrm{N}$ content increased from 1.30 to $2.15 \mathrm{~g} \mathrm{~m}^{-2}$, then remained relatively stable with further increasing leaf $\mathrm{N}$ content, whereas intercellular $\mathrm{CO}_{2}$ concentration decreased as leaf $\mathrm{N}$ content increased

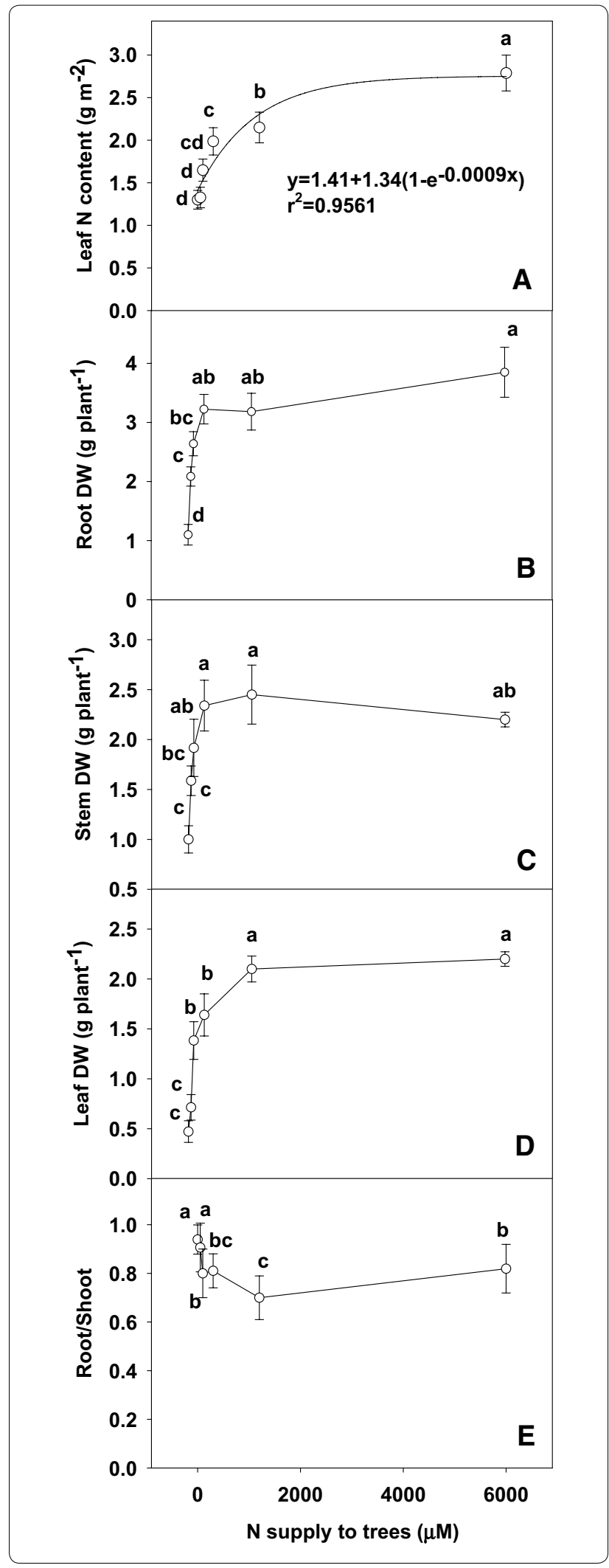


Fig. 2 Total soluble protein $(\mathbf{A})$, Chl a content (B), Chl b content (C), Chl content $(\mathbf{D})$ and $\mathrm{Chl}$ a/b $(\mathbf{E})$ in relation to $\mathrm{N}$ content $(1.30,1.32$, $1.65,1.99,2.15$ and $2.79 \mathrm{~g} \mathrm{~m}^{-2}$ ) in tea leaves. The data were examined using a LSD test. Each point is mean \pm standard error for the leaf $\mathrm{N}$ content (horizontal, $\mathrm{n}=5$ ) and the dependent variable (vertical, $\mathrm{n}=4$ ). Different letters above or below standard error bars indicate significant difference at $P<0.05$

from 1.30 to $1.65 \mathrm{~g} \mathrm{~m}^{-2}$, then increased from as leaf $\mathrm{N}$ content increased from 1.99 to $2.79 \mathrm{~g} \mathrm{~m}^{-2}$ (Fig. 3C).

Both initial and total Rubisco activity kept relatively constant as leaf $\mathrm{N}$ content decreased from 2.79 to $1.99 \mathrm{~g} \mathrm{~m}^{-2}$, and then decreased significantly with further decreasing leaf $\mathrm{N}$ content from 1.99 to $1.30 \mathrm{~g} \mathrm{~m}^{-2}$ (Fig. 4A, C), whereas both initial and total activity expressed on a protein basis did not change significantly, except decreased significantly as leaf $\mathrm{N}$ content decreased from 1.33 to $1.30 \mathrm{~g} \mathrm{~m}^{-2}$ (Fig. 4B, D). Rubisco activation state remained unchanged as leaf $\mathrm{N}$ content decreased from 2.79 to $1.65 \mathrm{~g} \mathrm{~m}^{-2}$, and then dropped as leaf $\mathrm{N}$ content decreased from 1.33 to $1.30 \mathrm{~g} \mathrm{~m}^{-2}$ (Fig. 4E).

\section{Leaf nonstructural carbohydrates}

On an area basis, contents of glucose and fructose content did not change significantly as leaf $\mathrm{N}$ content decreased from 2.79 to $2.15 \mathrm{~g} \mathrm{~m}^{-2}$ and then dropped significantly as leaf $\mathrm{N}$ content decreased from 1.99 to $1.30 \mathrm{~g} \mathrm{~m}^{-2}$ (Fig. 5A, B). The sucrose content increased successive over the range of leaf $\mathrm{N}$ content from 1.30 to $2.79 \mathrm{~g} \mathrm{~m}^{-2}$ (Fig. 5C). Leaf starch content remained little changed as leaf $\mathrm{N}$ content increased from 1.30 to $1.33 \mathrm{~g} \mathrm{~m}^{-2}$, then increased significantly with further increasing leaf $\mathrm{N}$ content (Fig. 5D).

\section{Leaf chlorophyll fluorescence transients and related parameters}

The chlorophyll fluorescence transients of leaves from 0 , 50 and $100 \mu \mathrm{M}$ N-treated trees showed a large depression at the P-step (Fig. 6A). Figure 6C and D shows the kinetics of relative variable fluorescence at any time $\mathrm{V}_{\mathrm{t}}=\left(\mathrm{F}_{\mathrm{t}}-\mathrm{F}_{\mathrm{o}}\right) /\left(\mathrm{F}_{\mathrm{m}}-\mathrm{F}_{\mathrm{o}}\right)$ and the differences of normalized N-treated transients minus $6000 \mu \mathrm{M}$ N-treated transient $\left(\Delta \mathrm{V}_{\mathrm{t}}\right)$. The differences revealed two obvious bands: increase in the $2-4 \mathrm{~ms}$ range J-step and in the 30-100 ms range I-step. The positive J and I-steps were very pronounced in the leaves from 0,50 and $100 \mu \mathrm{M}$ N-treated trees. Figure 6E and F depicts the relative variable fluorescence between $F_{o}$ and $F_{300 \mu s}\left(W_{K}\right)$ and the differences of normalized $\mathrm{N}$-treated transients minus $6000 \mu \mathrm{M} \mathrm{N}$-treated transient $\left(\Delta \mathrm{W}_{\mathrm{K}}\right)$. The differences showed a clear L-step in the leaves from 0,50

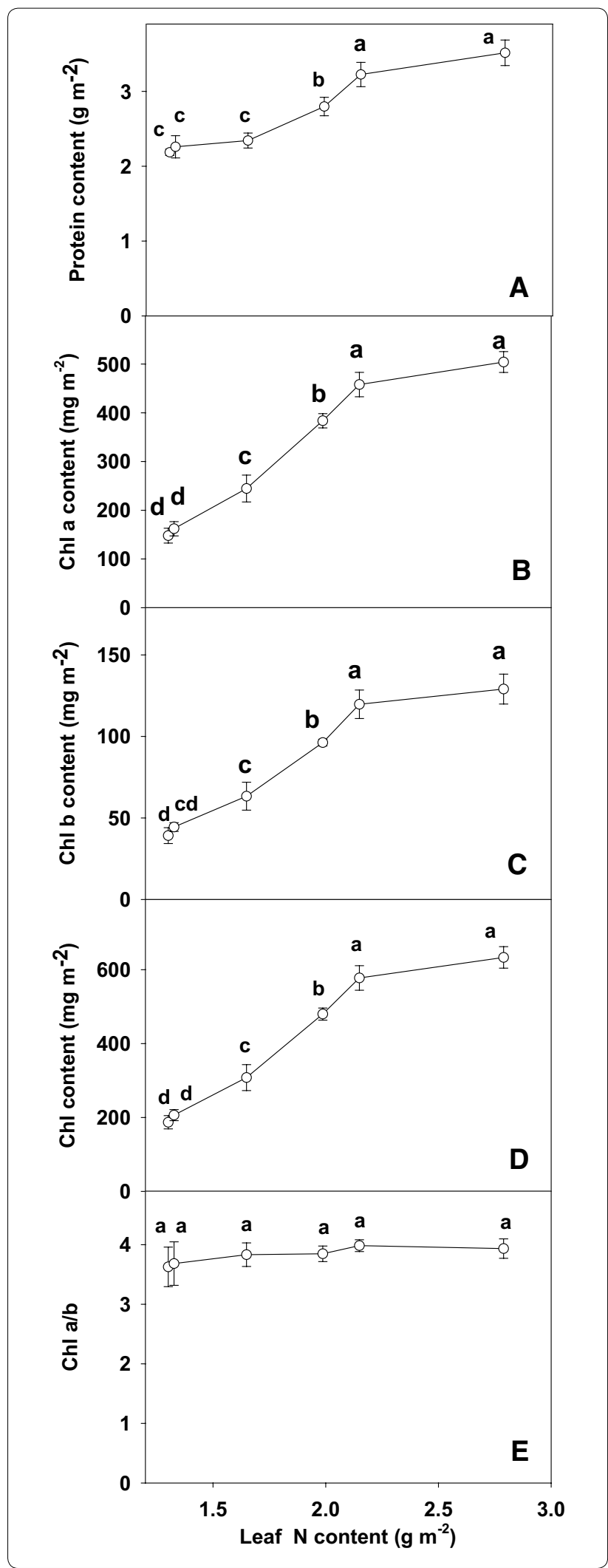




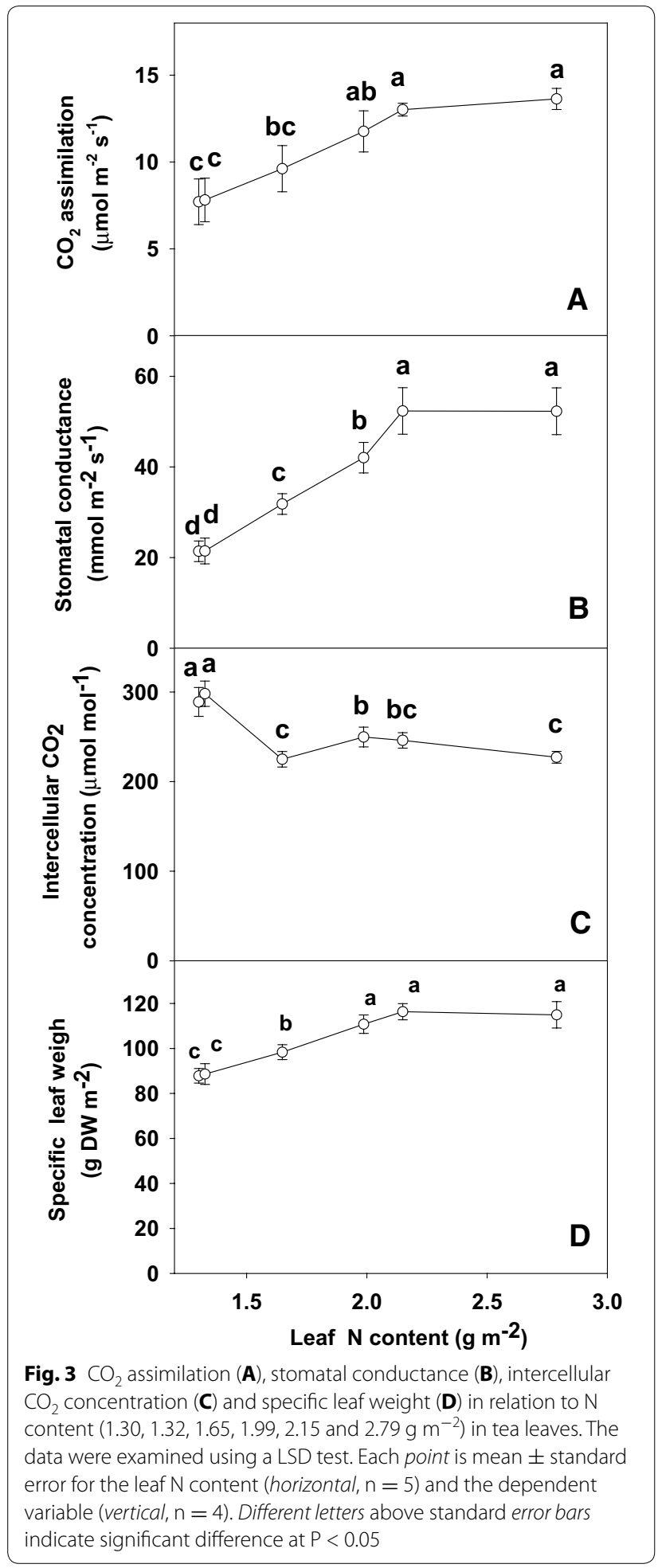

and $100 \mu \mathrm{M} N$-treated trees. Figure $6 \mathrm{~B}$ depicts from 0 to $100 \mu \mathrm{M} \mathrm{N}$-treated trees had decreased maximum amplitude of IP phase and rise time, and the end-levels were lowered by $\mathrm{N}$ deficiency. According to Fig. 7, each parameter the values were normalized on that of the sample treated with $6000 \mu \mathrm{M} \mathrm{N}$-treated trees. The result showed that leaves $\mathrm{N}$ content from 1.30 to $1.65 \mathrm{~g} \mathrm{~m}^{-2}$ had decreased $\mathrm{F}_{\mathrm{v}} / \mathrm{F}_{\mathrm{m}}, \mathrm{RE}_{\mathrm{o}} / \mathrm{ET}_{\mathrm{o}}, \mathrm{ET}_{\mathrm{o}} / \mathrm{ABS}, \mathrm{S}_{\mathrm{m}}$ (Fig. 7A), $\mathrm{ET}_{\mathrm{o}} /$ $\mathrm{CS}_{\mathrm{o}}, \mathrm{PI}_{\mathrm{abs}}, \mathrm{PI}_{\text {tot, abs }}$, (Fig. 7B), but increased $\mathrm{DI}_{\mathrm{o}} / \mathrm{CS}_{\mathrm{o}}, \mathrm{DI}_{\mathrm{o}} /$ $\mathrm{RC}$ and $\mathrm{DI}_{\mathrm{o}} / \mathrm{ABS}$ (Fig. 7C).

\section{Leaf $\mathrm{Pl}_{\text {abs }}$, initial rubisco activity and $\mathrm{Chl}$ content in relation to $\mathrm{CO}_{2}$ assimilation}

Leaf $\mathrm{CO}_{2}$ assimilation increased linearly or curvilinearly with increasing $\mathrm{PI}_{\mathrm{abs}}$ (Fig. 8A), initial rubisco activity (Fig. 8B) and Chl content (Fig. 8C), respectively.

\section{Discussion}

Nitrogen is one of the most important nutrients for crop growth and development because it affects dry matter production by influencing the leaf area development and maintenance as well as photosynthetic efficiency (Zhu et al. 2014). Nearly all physiological and biochemical activities reached their maximum in the leaves of about $2.15 \mathrm{~g} \mathrm{~m}^{-2}$ from $300 \mu \mathrm{M} \mathrm{N}$-treated trees (Figs. 2, 3, 4, 5, $6,7)$. Based on these results, trees treated with 0,50 or $100 \mu \mathrm{M} \mathrm{N}$ are considered $\mathrm{N}$ deficient.

The present work (Fig. 1), like that of previous workers (Chen and Cheng 2004; Chen et al. 2015; Zhu et al. 2014) indicates that $\mathrm{N}$ deficiency suppressed $\mathrm{N}$ content, plant growth and DM accumulation. $\mathrm{N}$ deficiency resulted in an increase in the ratio of root/shoot dry weight (Fig. 1E) which agrees with the view that plant tops are affected by $\mathrm{N}$ deficiency to a greater extent than root systems (Chen et al. 2015).

Leaf Chl a, b and total Chl (Fig. 2A-C) concentration were closely correlated with leaf $\mathrm{N}$ level decreased linearly as leaf $\mathrm{N}$ concentration decreased, except for leaf $\mathrm{N}$ content from 2.79 to $2.15 \mathrm{~g} \mathrm{~m}^{-2}$, indicating that leaf $\mathrm{N}$ no longer limited $\mathrm{Chl}$. These results agree with earlier reports in Grape (Chen and Cheng 2004), sorghum (Zhao et al. 2005), apple (Chen and Cheng 2004) and in corn (Zhao et al. 2003).

$\mathrm{N}$ limitation significantly reduced both $\mathrm{CO}_{2}$ assimilation and stomatal conductance of tea leaves (Fig. 3A, B), but higher intercellular $\mathrm{CO}_{2}$ concentration in low $\mathrm{N}$ leaves (Fig. 3C). These indicates that the low $\mathrm{CO}_{2}$ assimilation under $\mathrm{N}$ limitation was caused by non-stomatal factors (Bondada and Syvertsen 2005). Decreases in $\mathrm{CO}_{2}$ assimilation accompanied by an increase in intercellular $\mathrm{CO}_{2}$ concentration due to $\mathrm{N}$ deprivation has also been reported in wheat (Triticum aestivum L.) (Evans 1983), citrus (Bondada and Syvertsen 2005) and Grape (Chen and Cheng 2004). However, the decrease of assimilation $\mathrm{CO}_{2}$ rate under $\mathrm{N}$ deficiency was accompanied by 


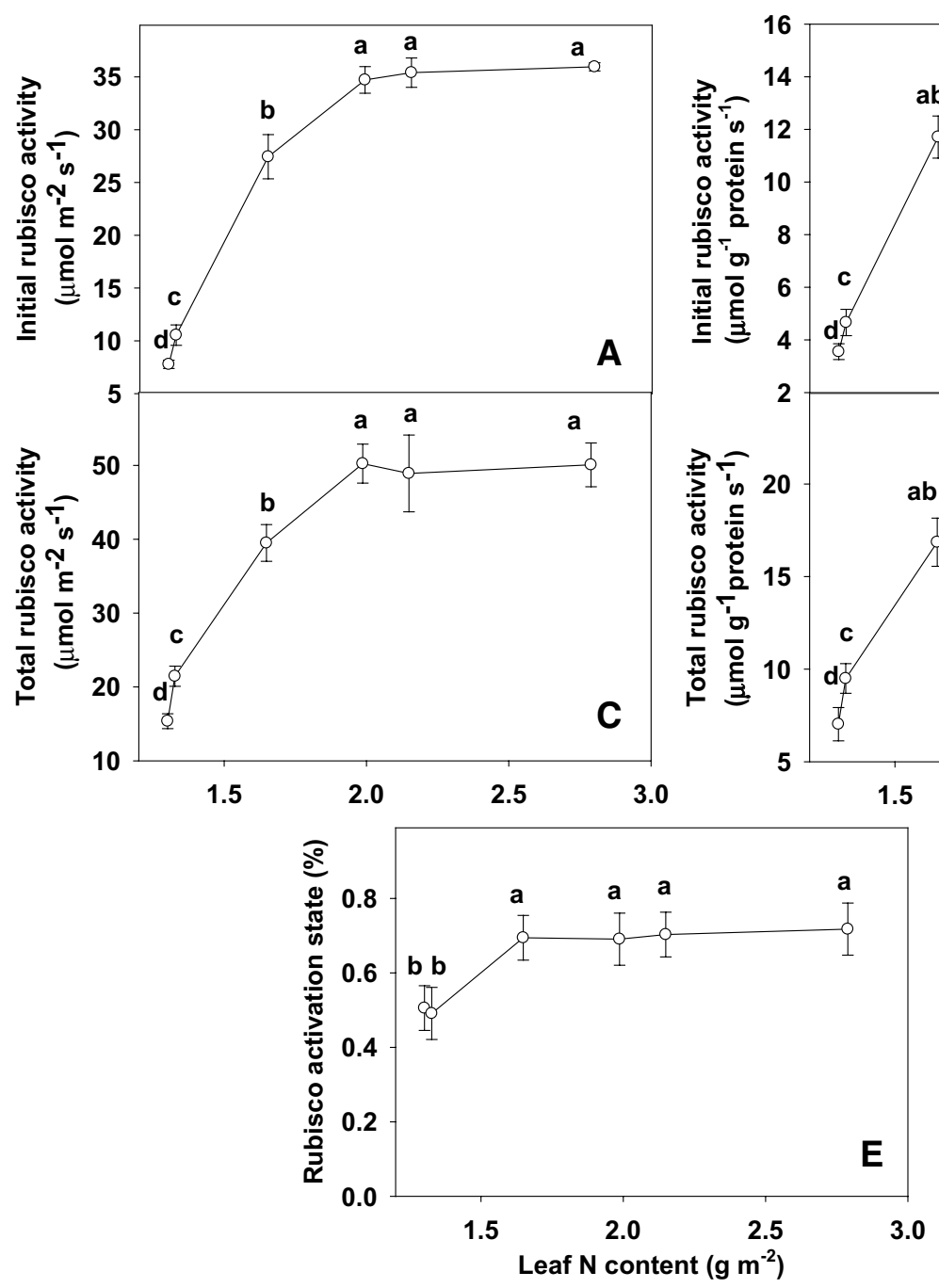

Fig. 4 Initial ribulose-1,5-bisphosphate carboxylase/oxygenase (Rubisco) activity (A) or expressed on a protein basis (B), total Rubisco activity (C) or expressed on a protein basis $(\mathbf{D})$, and Rubisco activation state $(\mathbf{E})$ in relation to $\mathrm{N}$ content $\left(1.30,1.32,1.65,1.99,2.15\right.$ and $\left.2.79 \mathrm{~g} \mathrm{~m}^{-2}\right)$ in tea leaves. The data were examined using a LSD test. Each point is mean \pm standard error for the leaf $\mathrm{N}$ content (horizontal, $\mathrm{n}=5$ ) and the dependent variable (vertical, $\mathrm{n}=4$ ). Different letters above or below standard error bars indicate significant difference at $\mathrm{P}<0.05$

a decrease in the starch accumulation (Fig. 5D), as previously reported for P deficiency of tea (Lin et al. 2009). This indicates that the production, rather that the utilization of photosynthates, is limiting. The results showed that $\mathrm{N}$-deficiency significantly reduced the contents of glucose (Fig. 5A), fructose (Fig. 5B) and sucrose (Fig. 5C). However, $\mathrm{N}$ deficiency was probably not the primary factor limiting $\mathrm{CO}_{2}$ assimilation, because there was a greater decrease in $\mathrm{CO}_{2}$ assimilation than in sugars content. Evidence shows that soluble sugars, specifically hexoses, may repress photosynthetic gene expression, particularly of the nuclear-encoded small sub-unit of Rubisco, thus decreasing Rubisco content and $\mathrm{CO}_{2}$ assimilation (Lin et al. 2009, 2010).

Earlier studies in several other crops indicated that $\mathrm{N}$ deficiency reduced either Rubisco activity (Heitholt et al. 1991; Chen and cheng 2004) or the amount of the enzyme (Osaki et al. 1993; Chen and cheng 2003).

In our study, initial and total Rubisco activity expressed on an area basis were closely correlated with leaf $\mathrm{N}$ level decreased linearly as leaf $\mathrm{N}$ concentration decreased, except for leaf $\mathrm{N}$ content from 2.79 to $1.99 \mathrm{~g} \mathrm{~m}^{-2}$, indicating that leaf $\mathrm{N}$ no longer limited Rubisco activity. Similar result has been obtained 

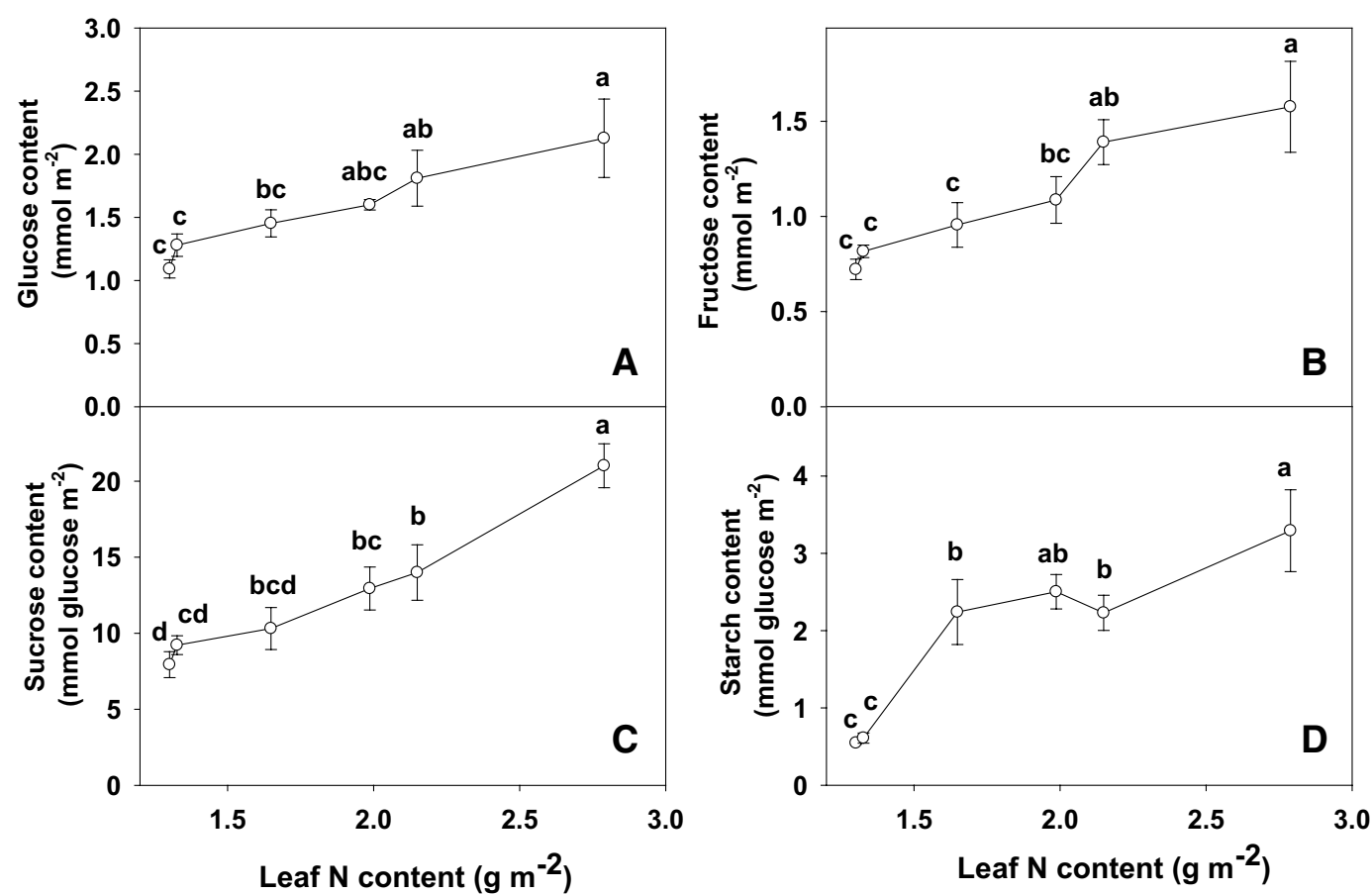

Fig. 5 Glucose $(\mathbf{A})$, fructose $(\mathbf{B})$, sucrose $(\mathbf{C})$, and starch (D) contents in relation to $\mathrm{N}$ content $\left(1.30,1.32,1.65,1.99,2.15\right.$ and $\left.2.79 \mathrm{~g} \mathrm{~m}^{-2}\right)$ in tea leaves. The data were examined using a LSD test. Each point is mean \pm standard error for the leaf $\mathrm{N}$ content (horizontal, $\mathrm{n}=5$ ) and the dependent variable (vertical, $\mathrm{n}=4$ ). Different letters above standard error bars indicate significant difference at $\mathrm{P}<0.05$

for apple (Chen and cheng 2004) and Grape (Chen and cheng 2003). The decrease in $\mathrm{CO}_{2}$ assimilation in $\mathrm{N}$-deficient leaves can not be attributed to a decrease in protein contents, because the decrease in leaf total soluble protein (Fig. 2A) contents was much less than $\mathrm{CO}_{2}$ assimilation. Similar results have been reported for maize (Wei et al. 2016), sorghum (Zhao et al. 2005), Olive (Boussadia et al. 2010).

It was well documented that the nitrogen nutrition influences the plant photosynthetic capacity (Terashima and Evans 1988; Živčák et al. 2014). Thus, the membrane processes must be balanced to maintain high efficiency in the conversion of energy and to avoid the over-reduction of photosynthetic electron chain in conditions with different nitrogen supply (Tóth et al. 2007). The decrease of $F_{v} / F_{m}$ in $\mathrm{N}$-deficient leaves was caused by a decrease in $\mathrm{F}_{\mathrm{m}}$ (Fig. 6A, B), as previously found for corn (Jin et al. 2015), maize (Wei et al. 2016) and wheat (Živčák et al. 2014). The decrease in $F_{v} / F_{m}$ under stress is considered to reflect the photo inhibitory damage to PSII complexes (Baker and Eva-Rosenqvist 2004).The J-step, I-step and IP phase of chlorophyll fluorescence transients are correlated with the redox state of $\mathrm{Q}_{\mathrm{A}}$, the redox state of plastoquinone, and the redox state of end acceptors at PSI electron acceptor side, respectively (Lazár 2006; Schansker et al. 2005). The finding that $\mathrm{N}$-deficient leaves had increased $V_{\text {J }}$ and $V_{I}$ (Fig. 6C, D), but decreased maximum amplitude of IP phase (Fig. 6B) suggests that acceptor side of PSII became more reduced under $\mathrm{N}$ deficiency, but the acceptor side of PSI become more oxidized. A positive L-step appeared at ca. $150 \mu$ s in the chlorophyll fluorescence transients in N-deficient leaves (Fig. 6E). This means that the oxygen evolving complex (OEC) is damaged (Hakala et al. 2005). A positive L-step has also been found in N-deficient cowpea leaves (Strasser et al. 1995).

We found that $\mathrm{N}$ deficiency decreased $\mathrm{F}_{\mathrm{v}} / \mathrm{F}_{\mathrm{m}}, \mathrm{RE}_{\mathrm{o}} / \mathrm{ET}_{\mathrm{o}}$, $\mathrm{ET}_{\mathrm{o}} / \mathrm{ABS}, \mathrm{S}_{\mathrm{m}}, \mathrm{ET}_{\mathrm{o}} / \mathrm{CS}_{\mathrm{o}}, \mathrm{PI}_{\mathrm{abs}}, \mathrm{PI}_{\text {tot, abs }}$ (Fig. 7A, B) and increased $\mathrm{DI}_{\mathrm{o}} / \mathrm{CS}_{\mathrm{o}}, \mathrm{DI}_{\mathrm{o}} / \mathrm{RC}$ and $\mathrm{DI}_{\mathrm{o}} / \mathrm{abs}$ (Fig. $7 \mathrm{C}$ ). This means that $\mathrm{N}$-deficient leaves damaged all of the photochemical and non- photochemical redox reactions and had a decreased capacity for electron transport, thus limiting ATP synthesis and RuBP regeneration. Regressive analysis showed that $\mathrm{CO}_{2}$ assimilation decreased linearly 

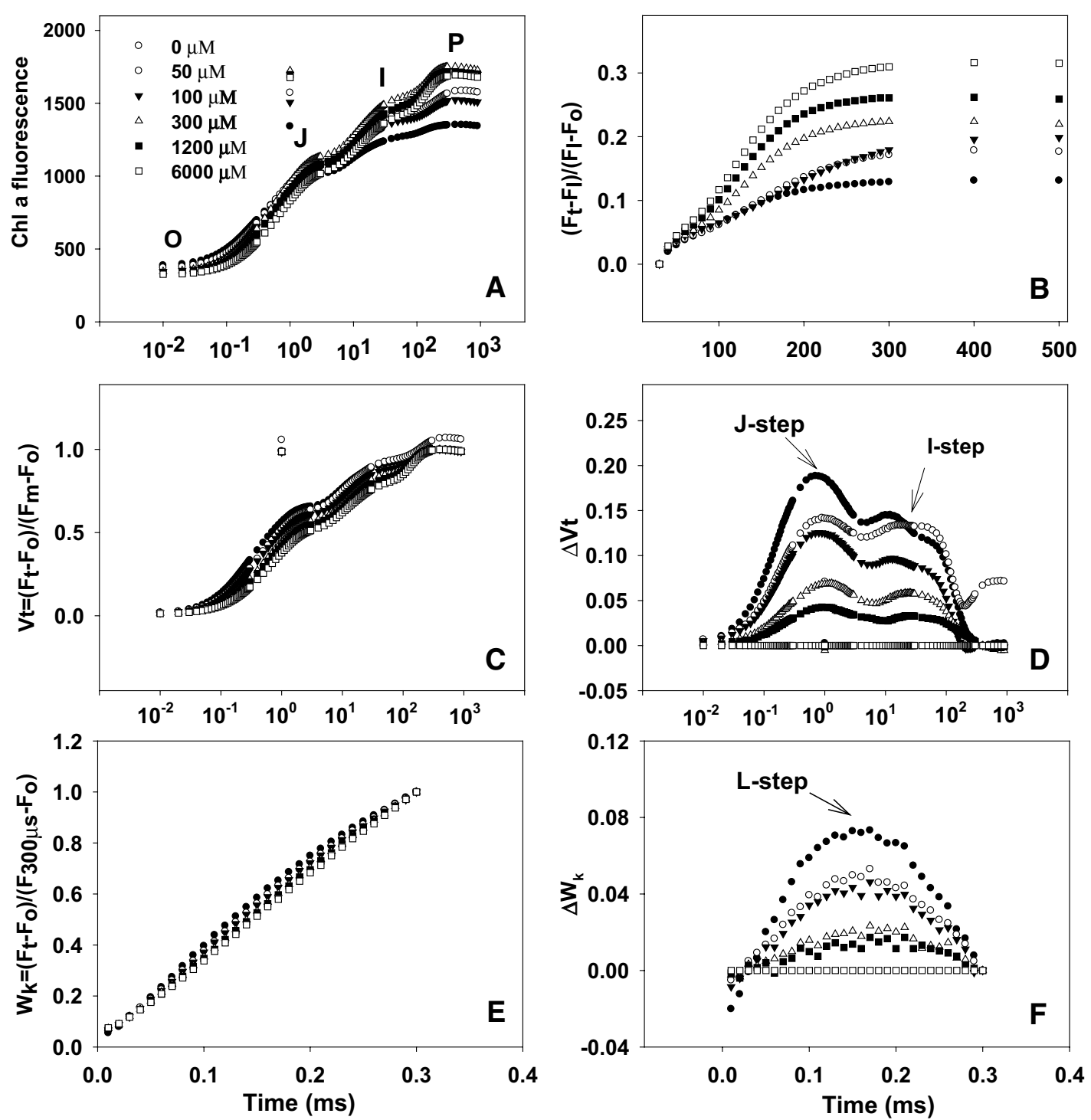

Fig. 6 Average chlorophyll fluorescence transients (average of 7-8 samples, $\mathbf{A}$ ) and the different expressions of relative variable fluorescence: (C) between $F_{0}$ and $F_{m}: V_{t}=\left(F_{t}-F_{0}\right) /\left(F_{m}-F_{0}\right)$ and $(\mathbf{D})$ the differences of the six samples to the reference sample treated with $6000 \mu M N\left(\Delta V_{t}\right)$, (E) between $F_{0}$ and $F_{300 \mu s}: W_{K}=\left(F_{t}-F_{0}\right) /\left(F_{300 \mu s}-F_{0}\right)$ and $\mathbf{F}$ the differences of the six samples to the reference sample $\left(\Delta W_{K}\right),(B) I P$ phase: $\left(F_{t}-F_{0}\right) /\left(F_{l}-F_{0}\right)-1=\left(F_{t}-F_{l}\right) /\left(F_{l}-F_{0}\right)$ in dark-adapted tea leaves under different $N$ supply $\left(0,50,100,300,1200\right.$ and $\left.6000 \mu \mathrm{mol} \mathrm{L}^{-1}\right)$

or curvilinearly with decreasing initial rubisco (Fig. 8A), $\mathrm{PI}_{\text {abs }}$ (Fig. 8B) and Leaf Chl (Fig. 8C), respectively. Therefore, we concluded the decreased photosynthetic electron transport capacity, leaf chl content and initial rubisco activity are probably the main factors contributing to decreased $\mathrm{CO}_{2}$ assimilation under $\mathrm{N}$ deficiency. 


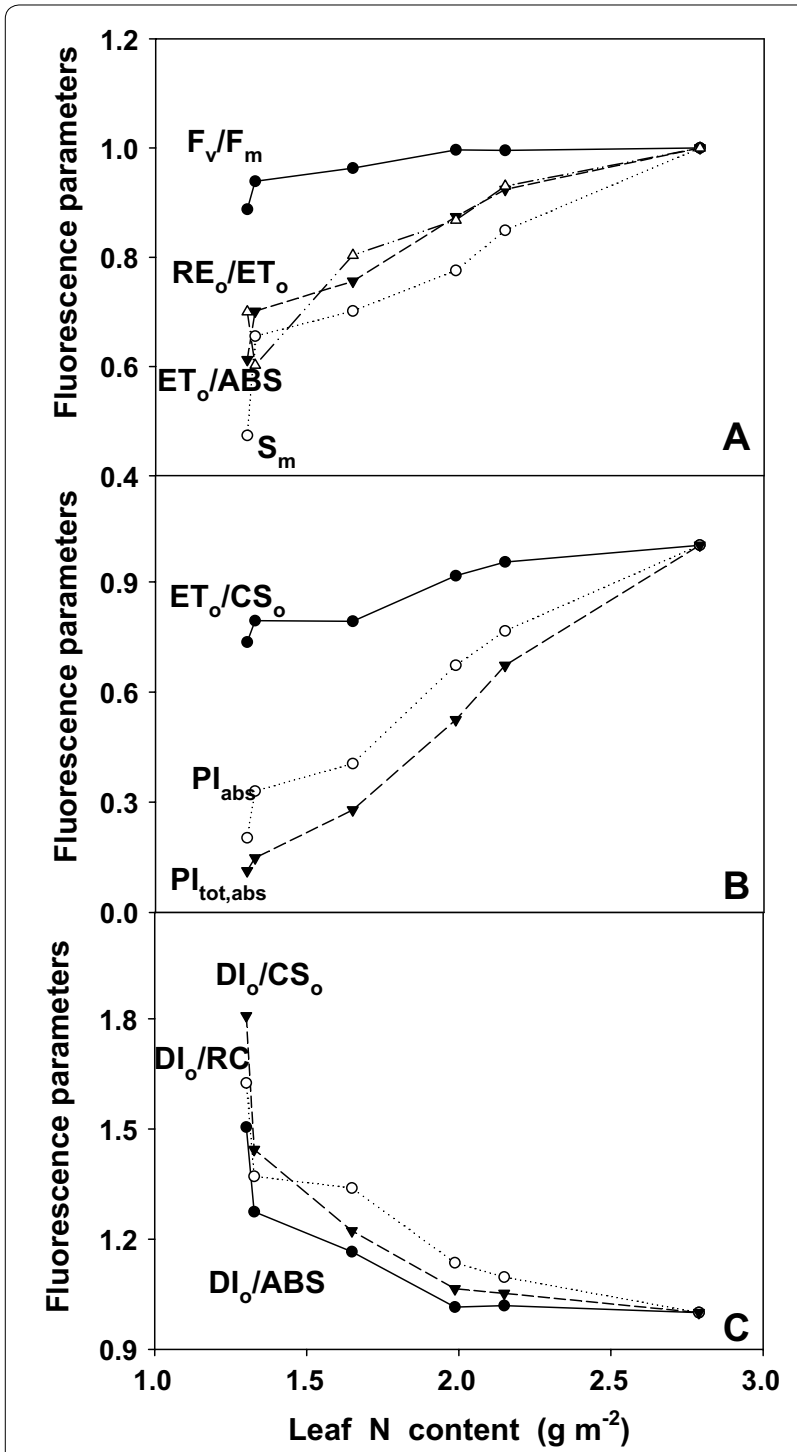

Fig. 7 Nine fluorescence parameters $\left(\mathbf{A} F_{v} / F_{m}, R E_{0} / E T_{0}, E T_{0} / A B S ; \mathbf{B}\right.$ $\mathrm{ET}_{\mathrm{o}} / \mathrm{CS}, \mathrm{Pl}_{\text {abs' }} \mathrm{Pl}_{\text {tot' abs' }} ; \mathbf{C} \mathrm{DI}_{\mathrm{o}} / \mathrm{CS}_{\mathrm{o}}, \mathrm{DI}_{\mathrm{o}} / \mathrm{ABS}, \mathrm{DI} / \mathrm{RC}$ ) derived from the average chlorophyll fluorescence transients of Fig. $6 \mathrm{~A}$ in relation to $\mathrm{N}$ content $\left(1.30,1.32,1.65,1.99,2.15\right.$ and $\left.2.79 \mathrm{~g} \mathrm{~m}^{-2}\right)$ in tea leaves. $\mathrm{F}_{\mathrm{v}} / \mathrm{F}_{\mathrm{m}}$ : Maximum quantum yield of primary photochemistry; $\mathrm{RE}_{\mathrm{o}} /$ $\mathrm{ET}_{\mathrm{O}}$ : Efficiency with which an electron can move from the reduced intersystem; $\mathrm{ET}_{0} / \mathrm{ABS}$ : Quantum yield for electron transport; $\mathrm{ET}_{0} /$ CS:Electron transport flux per $\mathrm{CS}_{\mathrm{P}} \mathrm{Pl}_{\mathrm{abs}}$ : Performance index (PI) on absorption basis; $\mathrm{PI}_{\text {tot' abs: }}$ :Total PI, measuring the performance up to the PSI end electron acceptors; $\mathrm{DI}_{0} / \mathrm{CS}_{0}$ : Dissipated energy flux per CS; DI/ABS: Quantum yield for energy dissipation; $\mathrm{DI}_{\mathrm{o}} / \mathrm{RC}$ : Dissipated energy flux per RC. All the values were expressed relative to the sample treated with $6000 \mu \mathrm{M} \mathrm{N}$ set as 1

\section{Conclusions}

Assessing the impact of $\mathrm{N}$ deficiency on $\mathrm{CO}_{2}$ assimilation and photosynthetic electron transport of tea plant is

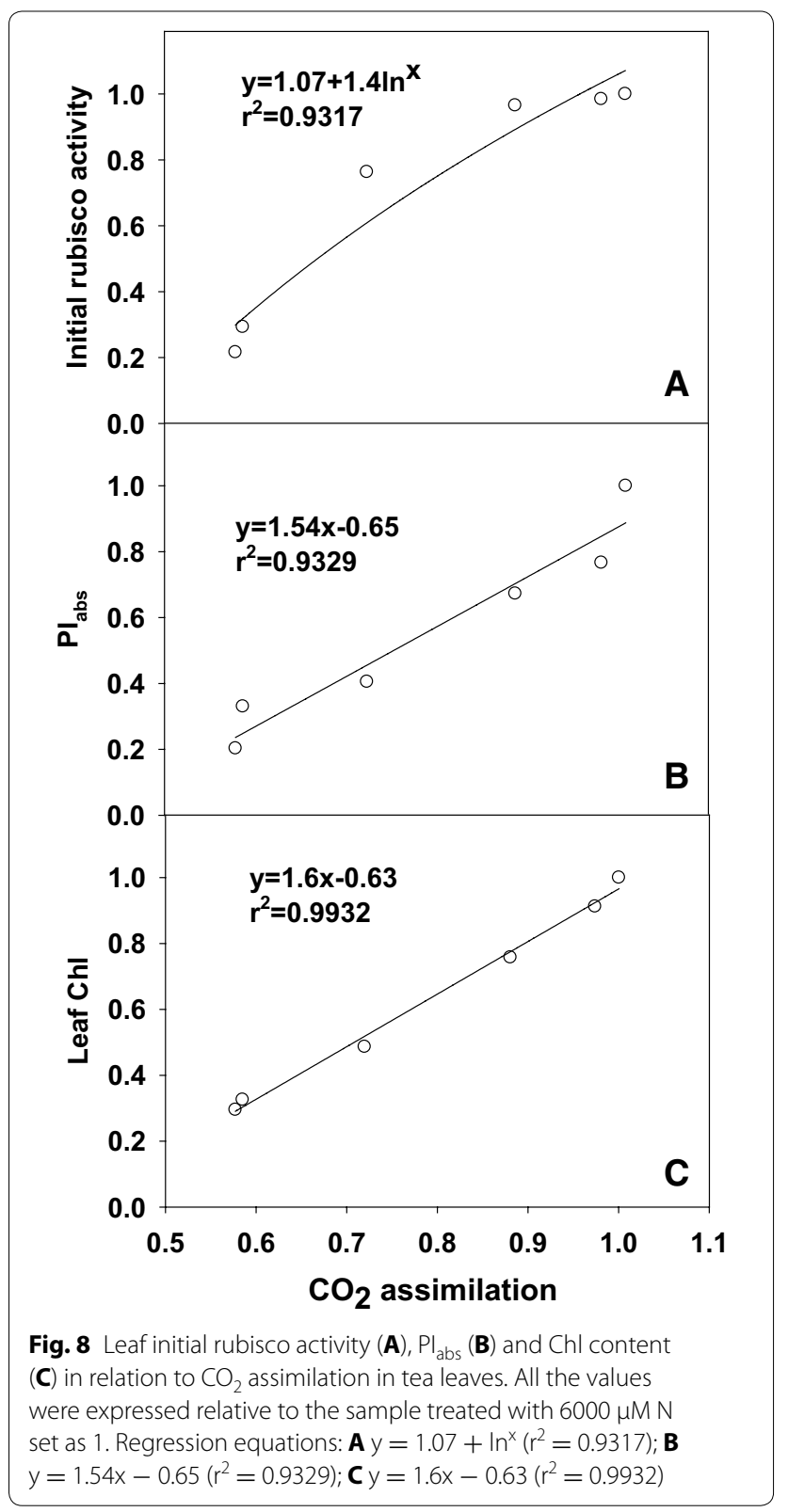

important to improve the utilisation efficiency of $\mathrm{N}$ fertilisers and assist in developing better methods to evaluate plant responses to possible deficiencies. This study demonstrated how $\mathrm{N}$ deficiency affects $\mathrm{CO}_{2}$ assimilation, Rubisco, non-structural carbohydrates and photosynthetic electron transport in tea leaves to understand the mechanism by which $\mathrm{N}$ deficiency leads to a decrease in $\mathrm{CO}_{2}$ assimilation. The results indicated that the decreased photosynthetic electron transport capacity, leaf chl content and initial rubisco activity are probably the main factors contributing to decreased $\mathrm{CO}_{2}$ assimilation under $\mathrm{N}$ deficiency. 


\section{Abbreviations}

Rubisco: ribulose-1,5-bisphosphate carboxylase/oxygenase; PSII: photosystem $\mathrm{II}_{;} \mathrm{PI}_{\mathrm{abs}}$ : performance index (PI) on absorption basis; $\mathrm{N}$ deficiency: nitrogen deficiency; Chl: chlorophyll; OEC: oxygen evolving complex; DW: dry weigh; BSA: bovine serum albumin; RuBP: ribulose-1,5-bisphosphate.

\section{Authors' contributions}

ZHL performed most of the experiments and wrote the manuscript. QSZ helped in designing the study. CSC designed and directed the study and revised the manuscript. QCR performed the experiments and analyzed the data. ZHC and XMY analyzed data. All authors have read and approved the final manuscript.

\section{Acknowledgements}

This work was supported by the National Natural Science Foundation of China (31570690) and Modern Agro-Industry Technology Research System (nycytx-23).

\section{Competing interests}

The authors declare that they have no competing interests.

Received: 26 August 2016 Accepted: 5 November 2016 Published online: 17 November 2016

\section{References}

Baker NR, Eva-Rosenqvist E (2004) Applications of chlorophyll fluorescence can improve crop production strategies: an examination of future possibilities. J Exp Bot 55:1607-1621

Bondada BR, Syvertsen JP (2005) Concurrent changes in net $\mathrm{CO}_{2}$ assimilation and chloroplast ultrastructure in nitrogen deficient citrus leaves. Environ Exp Bot 54:41-48

Boussadia O, Steppe K, Zgallai H, Ben EH, Braham M, Lemeur R, Van-Labeke MC (2010) Effects of nitrogen deficiency on leaf photosynthesis, carbohydrate status and biomass production in two olive cultivars 'Meski' and 'Koroneiki'. Sci Hortic 123:336-342

Bradford MM (1976) A rapid and sensitive method for quantitation of microgram quantities of protein utilizing the principle of protein-dye binding Anal Biochem 72:248-254

Brestič M, Živčák M, Kalaji HM, Carpentier R, Allakhverdiev SI (2012) Photosystem II thermostability in situ: environmentally induced acclimation and genotype-specific reactions in Triticum aestivum L. Plant Physiol Biochem 57:93-105

Chen LS, Cheng L (2003) Carbon assimilation and carbohydrate metabolism of concord grape (Vitis labrusca L.) leaves in response to nitrogen supply. J Am Soc Hortic Sci 128(5):754-760

Chen LS, Cheng LL (2004) Photosynthetic enzymes and carbohydrate metabolism of apple leaves in response to nitrogen limitation. J Hortic Sci Biotechnol 79(6):923-929

Chen PA, Lin SY, Liu CF, Su YS, Cheng HY, Shi JH, Chen IZ (2015) Correlation between nitrogen application to tea flushes and quality of green and black teas. Sci Hortic 181:102-107

Evans JR (1983) Nitrogen and photosynthesis in the flag leaf of wheat (Triticum aestivum L.). Plant Physiol 72:297-302

Fu X, Li Y, Su W, Shen J, Xiao R, Tong C, Wu J (2012) Annual dynamics of $\mathrm{N}_{2} \mathrm{O}$ emissions from a tea field in southern subtropical China. Plant Soil Environ 58:373-378

Hakala M, Tuominen I, Keränen M, Tyystjärvi T, Tyystjärvi E (2005) Evidence for the role of the oxygen-evolving manganese complex in photoinhibition of photosystem II. Biochim Biophys 1706:68-80

Heitholt JJ, Johnson RC, Ferris DM (1991) Stomatal limitation to carbon dioxide assimilation in nitrogen and drought-stressed wheat. Crop Sci 31:135-139

Hirono Y, Nonaka K (2012) Nitrous oxide emissions from green tea fields in Japan: contribution of emissions from soil between rows and soil under the canopy of tea plants. Soil Sci Plant Nutr 58:384-392
Jaaffar Z, Gardner FP (1988) Canopy development, yield and market quality in peanut as affected by genotype and planting pattern. Crop Sci 28:299-305

Jin XL, Yang GJ, Tan CW, Zhao CJ (2015) Effects of nitrogen stress on the photosynthetic $\mathrm{CO}_{2}$ assimilation, chlorophyll fluorescence, and sugar-nitrogen ratio in corn. Sci Rep 5:1-6

Jumadi O, Hala Y, Anas I, Ali A, Sakamoto K, Saigusa M, Yagi K, Inubushi K (2008) Community stucture of ammonia oxidizing bacteria and their potential to produce nitrous oxide and carbon dioxide in acid tea soils. Geomicrobiol J 25:381-389

Kalaji HM, Carpentier R, Llakhverdiev SI, Bosa K (2012) Fluorescence parameters as early indicators of light stress in barley. J Photochem Photobiol, B 112:1-6

Khokhar S, Magnusdottir SGM (2002) Total phenol, catechin, and caffeine contents of teas commonly consumed in the United Kingdom. J Agric Food Chem 50:565-570

Lazár D (2006) The polyphasic chlorophyll a fluorescence rise measured under high intensity of exciting light. Funct Plant Biol 33:9-30

Li Q, Chen LS, Jiang HX, Yang LT, Lin ZH, Li Y, Yang GH (2010) Effects of manganese-excess on $\mathrm{CO}_{2}$ assimilation, ribulose-1,5-bisphosphate carboxylase/oxygenase, carbohydrates and photosynthetic electron transport of leaves, and antioxidant systems of leaves and roots in Citrus grandis seedlings. BMC Plant Biol 10:42

Li G, Zhang ZS, Gao HY, Liu P, Dong ST, Zhang JW, Zhao B (2012) Effects of nitrogen on photosynthetic characteristics of leaves from two different stay-green corn (Zea mays L.) varieties at the grain-filling stage. Can J Plant Sci 92:671-680

Liang YR, Shi M (2015) Advances in tea plant genetics and breeding. J Tea Sci 35(2):103-109 (in chinese)

Lichtenthaler HK (1987) Chlorophylls and carotenoids: pigments of photosynthetic biomembranes. Method Enzymol 148:350-382

Lin ZH, Chen LS, Chen RB, Zhang FZ, Jiang HX, Tang N (2009) $\mathrm{CO}_{2}$ assimilation, ribulose-1,5-bisphosphate carboxylase/oxygenase, carbohydrates and photosynthetic electron transport probed by the JIP-test, of tea leaves in response to phosphorus supply. BMC Plant Biol 9:43

Lu C, Zhang J, Zhang Q, Li L, Kuang T (2001) Modification of photosystem II photochemistry in nitrogen deficient maize and wheat plants. J Plant Physiol 158:1423-1430

Osaki M, Shinano T, Tadano T (1993) Effect of nitrogen, phosphorus, or potassium deficiency on the accumulation of ribulose-1,5-bisphosphate carboxylase/oxygenase and chlorophyll in several field crops. Soil Sci Plant Nutr 39:417-425

Polesskaya OG, Kashirina El, Alekhina ND (2004) Changes in the activity of antioxidant enzymes in wheat leaves and roots as a function of nitrogen source and supply. Russian J Plant Physiol 51:615-620

Prinsi B, Negri AS, Pesaresi P, Cocucci M, Espen L (2009) Evaluation of protein pattern changes in roots and leaves of Zea mays plants in response to nitrate availability by two-dimensional gel electrophoresis analysis. BMC Plant Biol 9:113

Redillas MCFR, Jeong JS, Strasser RJ, Kim YS, Kim JK (2011) JIP analysis on rice (Oryza sativa cv. Nipponbare) grown under limited nitrogen conditions. J Korean Soc Appl Bi Chem 54:827-832

Schansker G, Tóth SZ, Strasser RZ (2005) Methylviologen and dibromothymoquin-one treatments of pea leaves reveal the role of photosystem I in the Chl a fluorescence rise OJIP. Biochim Biophys 1706:250-261

Scheible WR, Morcuende R, Czechowski T, Fritz C, Osuna D, Palacios-Rojas N, Schindelasch D, Thimm O, Udvardi MK, Stitt M (2004) Genome-wide reprogramming of primary and secondary metabolism, protein synthesis, cellular growth processes, and the regulatory infrastructure of Arabidopsis in response to nitrogen. Plant Physiol 136:2483-2499

Silva LS, Seabra AR, Leitão JN, Carvalho HG (2015) Possible role of glutamine synthetase of the prokaryotic type (GSI-like) in nitrogen signaling in Medicago truncatula. Plant Sci 240:98-108

Strasser RJ, Srivastava A et al (1995) Polyphasic chlorophyll a fluorescence transient in plants and cyanobacteria. Photochem Photobiol 61:32-42

Syvertsen JP, Bausher MG, Albrigo LG (1980) Water relations and related characteristics of healthy and blight affected citrus trees. J Am Soc Hortic Sci 105:431-434 
Terashima I, Evans JR (1988) Effects of light and nitrogen nutrition on the organization of the photosynthetic apparatus in spinach. Plant Cell Physiol 29:143-155

Tokuda S, Hayatsu M (2004) Nitrous oxide flux from a tea field amended with a large amount of nitrogen fertilizer and soil environmental factors controlling the flux. Soil Sci Plant Nutr 50:365-374

Topuz A, Dincer C, Torun M, Tontul I, Sahin-Nadeem H, Haznedar A, Ozdemir F (2014) Physicochemical properties of Turkish green tea powder: effects of shooting period, shading, and clone. Turk J Agric For 38:233-241

Tóth SZ, Schansker G, Garab G, Strasser RJ (2007) Photosynthetic electron transport activity in heat-treated barley leaves: the role of internal alternative electron donors to photosystem II. Biochim Biophys 1767:295-305

Wei SS, Wang XY, Shi DY, LiYH, Zhang JW, Liu P, Zhao B, Dong ST (2016) The mechanisms of low nitrogen induced weakened photosynthesis in summer maize (Zea mays L.) under field conditions. Plant Physiol Biochem 105:118-128

Yao Z, Wei Y, Liu C, Zheng X, Xie B (2015) Organically fertilized tea plantation stimulates $\mathrm{N}_{2} \mathrm{O}$ emissions and lowers $\mathrm{NO}$ fluxes in subtropical China. Biogeosciences 12:5915-5928

Zhao D, Reddy KR, Kakani VG, Read JJ, Carter GA (2003) Corn (Zea mays L.) growth, leaf pigment concentration, photosynthesis and leaf hyperspectral reflectance properties as affected by nitrogen supply. Plant Soil 257:205-217
Zhao DL, Reddy KR, Kakani VG, Reddy VR (2005) Nitrogen deficiency effects on plant growth, leaf photosynthesis, and hyperspectral reflectance properties of sorghum. Eur J Agron 22:391-403

Zhu Y, Fan XF, Hou XC, Wu JY, Wang T (2014a) Effect of different levels of nitrogen deficiency on switchgrass seedling growth. Crop J 2:223-234

Zhu T, Zhang J, Meng T, Zhang Y, Yang J, Müller C, Cai Z (2014b) Tea plantation destroys soil retention of $\mathrm{NO}_{3}{ }^{-}$and increase $\mathrm{N}_{2} \mathrm{O}$ emissions in subtropical China. Soil Biol Biochem 73:106-114

Živčák M, Brestič M, Olšovská K (2008) Physiological parameters useful in screening for improved tolerance to drought in winter wheat (Triticum aestivum L.). Cereal Res Commun 36:1943-1946

Živčák M, Slamka OP, Galambošová J, Rataj V, Shao HB, Brestič M (2014a) Application of chlorophyll fluorescence performance indices to assess the wheat photosynthetic functions influenced by nitrogen deficiency. Plant Soil Environ 60(5):210-215

Živčák M, Brestič M, Kalaji HM et al (2014b) Photosynthetic responses of sunand shade-grown barley leaves to high light: is the lower PSII connectivity in shade leaves associated with protection against excess of light? Photosynth Res 119:339-354

\section{Submit your manuscript to a SpringerOpen ${ }^{\circ}$ journal and benefit from:}

- Convenient online submission

- Rigorous peer review

- Immediate publication on acceptance

- Open access: articles freely available online

- High visibility within the field

- Retaining the copyright to your article 